\title{
Utilization rate and length-weight relationship of shortfin scad (Decapterus macrosoma) in Bali Strait Indonesia
}

\author{
Gatut Bintoro ${ }^{1, *}$, Ledhyane I. Harlyan ${ }^{1}$, Tri D. Lelono ${ }^{1}$, and Nofita A. Andini ${ }^{1}$ \\ ${ }^{1}$ Fisheries and Marine Science Faculty, Universitas Brawijaya, Veteran Street Malang East Java \\ Indonesia
}

\begin{abstract}
Shortfin scad (Decapterus macrosoma) is an essential economic fish resource that spreads over tropical and subtropical oceans and is mostly caught in Bali Strait. High market demand for this fish leads to an increase in fishing efforts. In contrast, uncontrolled fishing efforts will threaten its sustainability and economic potential. This research was conducted based on catches during February - March 2020 for total samples of 1,115 fish and catch-effort time series secondary data (2008-2019). Length-weight data were analyzed using linear regression. The utilization level is predicted using the surplus production model analysis, Schaefer and Fox models, to estimate maximum sustainable yield (MSY). Results informed that based on Fox model analysis, values of sustainable catch (YMSY), optimum fishing effort ( $f_{\text {opt }}$ ), and total allowable catch $\left(\mathrm{Y}_{\mathrm{TAC}}\right)$ were 1,585 tons/year, 1,782 trips/year, and 1,268 tons/year, respectively. The utilization rate value was $125 \%$. An increase in fishing efforts led to the excess amount of catch over the MSY level. In addition, based on length-weight relationship analysis, the growth pattern of shortfin scad (D. macrosoma) was found negative allometric with equation $\mathrm{W}=0.0175 \mathrm{~L}^{2.776}$. In conclusion, the fish has a fat body shape, and the stock is in overfishing condition.
\end{abstract}

\section{Introduction}

Shortfin scad (Decapterus macrosoma) comes from the Carangidae family, which is included in the genus Decapterus and is an important economic fish resource that spreads in overworld waters, both tropical and subtropical. This fish was found to dominate the over fisheries management area (FMA) of Indonesia with shallow waters conditions and lower salinity [1] [2].

Bali Strait is semi-enclosed water that connects the Bali Sea in the north and the Indian Ocean in the south. These waters have high fertility with various potential pelagic fishery resources, making this area potential as a small pelagic fishing area in Bali Province [3]. Shortfin scad (D. macrosoma) spreads in eastern Indonesian waters such as the Bali and Makassar Strait [4].

\footnotetext{
* Corresponding author: gbintoro@ub.ac.id
} 
Shortfin scad (D. macrosoma) is one of several fish species that dominate the catch of purse seines. This species is an economic fisheries resource that is affordable and in demand by the community. In Bali Strait, according to data given by Pengambengan Archipelago fishing port (AFP), the amount of shortfin scad (D. macrosoma) landed gradually increased from 1,273 tons in 2008 to 3,757 tons in 2019. The increased demand for shortfin scad $(D$. macrosoma) can trigger fishermen to increase their fishing efforts [5].

Shortfin scad is a commodity that has substantial economic value. Uncontrolled fishing will threaten its sustainability and economic potential. The high market demand has increased fishing efforts to reach the maximum catch. Although fish resources are "renewable resources," fishing that exceeds its carrying capacity will disrupt the balance of stocks [6]. Fishery resources are open access so that anyone can manage freely. An increase influences fishery production in open access conditions in the number of efforts. An uncontrolled effort will lead to excessive exploitation of resources [7].

Shortfin scad has low genetic diversity, which indicates that the fish resource has a more uniform genetic structure change. The factors that are thought to cause the change in the genetic structure of pelagic fish are fish behavior during the fishing season and pressure. Pelagic fish species have a high tendency to conduct migration activity. This condition causes cross or genetic mixing between populations so that the diversity of fish is reduced. The migration patterns emphasize the importance of managing resources wisely in biodiversity conservation by controlling the catch rate [8].

This research aimed to analyze biological aspects and estimate the shortfin scad (D. macrosoma) utilization rate caught in Bali Strait. These data can be used to analyze the status of fish resources in the southern waters of Java, especially in the Bali Strait waters.

\section{Materials and methods}

\subsection{Study area}

Primary data about the length-weight of fish were collected from February 2020-March 2020 based on the landing of a fishing vessel that conducted fishing activity at Bali Strait with coordinates 08028 '20' -8042 '27''S 114021'42'"-114054'54''E (Figure 1). At the same time, secondary data collection about the time series's catch effort data of shortfin scad $(D$. macrosoma) catch was done from January 2020-April 2020. Bali Strait is the waters located between the island of Java and the island of Bali. The Bali Strait is a relatively narrow water area (about 960 miles or $1776 \mathrm{~km}$ ) connecting the Flores Sea and Madura Strait in the north and the Indian Ocean in the south. The northern mouth is about one mile and is shallow (about 50 meters deep), while the southern part has a large area of about 28 miles $(51.8 \mathrm{~km})$, which is deep waters. The geographical location of the Bali Strait causes the waters of the Bali Strait to have many sources of nutrients food from fish so that it is a potential area for fisheries [9]. 


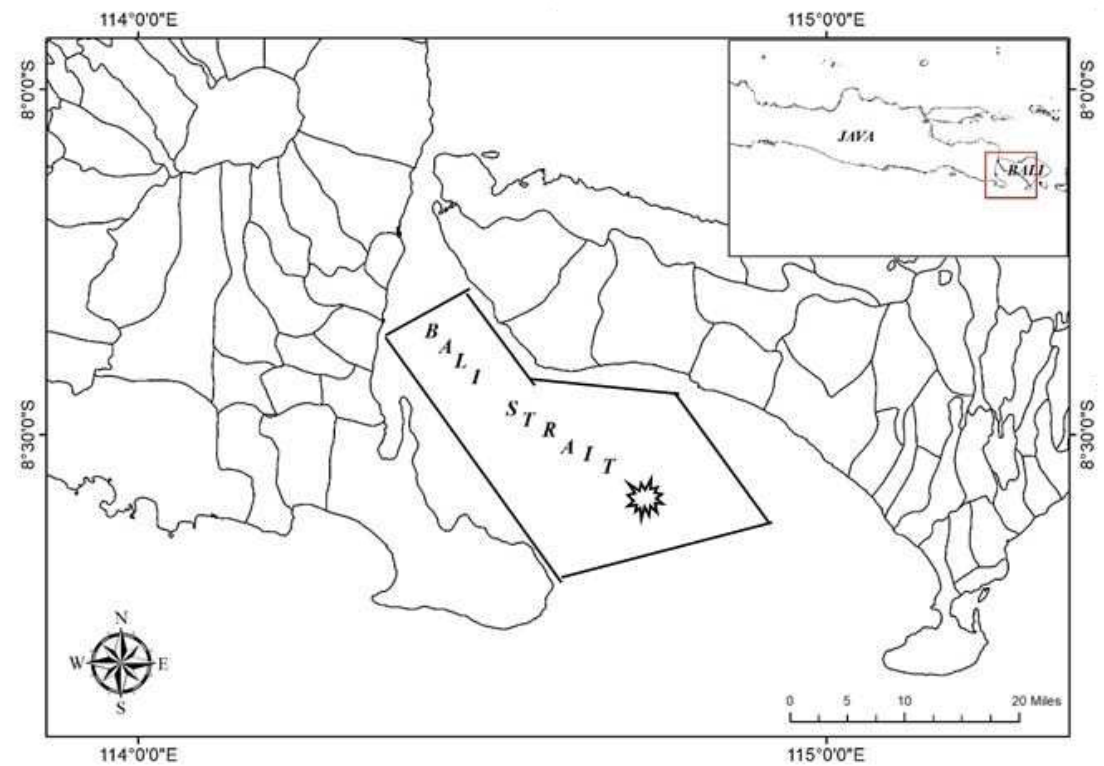

Fig. 1. Fishermen fishing activity area in Bali strait $\left(\frac{2}{m^{3}}\right)$

\subsection{Sampling method}

Primary data collection was samples of the catch landed at Pengambengan AFP. The data included the length and weight of fish. The measurement of the length and weight of shortfin scad ( $D$. macrosoma) begins by identifying the morphology of the fish. The length was measured from the top of the mouth at the front to the end of the tail (total length) using an elbow ruler measuring $50 \mathrm{~cm}$ with an accuracy level of $1 \mathrm{~mm}$. While weighing fish, used digital scales with an accuracy level of 1 gr. Sampling was carried out 11 times with a schedule of one to two sampling times a week. The minimum sample measured was 100 samples/day and the total sample observed was 1,115 fish.

At the same time, secondary data were also collected from statistic books of Pengambengan AFP obtained data on the production of Shortfin scad (D. macrosoma) and total fishing effort in 12 years starting from 2008 - 2019. Analysis of the data used to determine the estimated value of maximum Sustainable Yield (MSY), total allowable catch amount (TAC), and stock status of shortfin scad (D. macrosoma) using surplus production methods consisting of Schaefer (1954) and Fox (1970) models. The data used in the surplus production method are in the form of catch and effort.

\subsection{Surplus production method}

Using time-series data, estimating the maximum sustainable potential of a fish resource can be analyzed through the Schaefer (1954) and Fox (1970) models. The production surplus model is used to determine the optimum level of fishing effort so that the catch can be maximized without affecting the productivity of resource stocks in the long run. The appropriate model selection can be seen based on the $\mathrm{R}^{2}$ value or the coefficient of determination [10]. 


\subsection{Schaefer model (1954)}

Schaefer's model (1954) was used on a homogeneous stock (single stock). Based on Schaefer's (1954) model approach, the relationship between catch per unit effort (CpUE) and fishing effort (f) is linear and can be written in the form of regression (1) [11]:

$$
\mathrm{CpUE}=\mathrm{a}+\mathrm{bf}
$$

The relationship between catch and effort in the parabolic equation is as follow:

$$
\mathrm{Y}=\mathrm{af}+\mathrm{bf}^{2}
$$

The optimum fishing effort $\left(f_{\text {opt }}\right)$ is obtained by the following equation:

$$
\begin{aligned}
& Y^{1}=a+2 b f=0 \\
& f_{o p t}=(-a / 2 b)
\end{aligned}
$$

The MSY value can be obtained by substituting the $f_{\text {opt }}$ value into equation (2) so that equation (6) is obtained. Catch per catch ( $\left.\mathrm{U}_{\mathrm{MSY}}\right)$ can be calculated by comparing $\mathrm{Y}_{\mathrm{MSY}}$ and $f_{\text {opt. }}$

$$
\begin{gathered}
\mathrm{Y}_{\mathrm{MSY}}=\mathrm{a}(-\mathrm{a} / 2 \mathrm{~b})+\mathrm{b}\left(\mathrm{a}^{2} / 4 \mathrm{~b}^{2}\right) \\
\mathrm{MSY}=\left(-\mathrm{a}^{2} / 4 \mathrm{~b}\right) \\
\mathrm{U}_{\mathrm{MSY}}=\left(\mathrm{Y}_{\mathrm{MSY}} / \mathrm{fopt}\right)
\end{gathered}
$$

The allowable catch amount $\left(\mathrm{Y}_{\mathrm{TAC}}\right)$ is $80 \%$ of the MSY value. It can be calculated by the formula:

$$
\begin{aligned}
& \mathrm{Y}_{\mathrm{TAC}}=\left(-\mathrm{a}^{2} / 4 \mathrm{~b}^{2}\right) \times 80 \% \\
& \mathrm{Y}_{\mathrm{TAC}}=\mathrm{Y}_{\mathrm{MSY}} \times 80 \%
\end{aligned}
$$

\subsection{Fox model (1970)}

The assumption of Fox's (1970) exponential model [11] is that the population is considered not to be extinct. The relationship between CpUE and fishing effort (f) using the Fox model (1970) is an exponential form (10):

$$
\mathrm{Y}=\mathrm{f} \exp ^{(\mathbf{c}+\mathbf{d f})}
$$

The optimum fishing effort is calculated based on formula (11). The MSY value is obtained by plotting the value into the equation (12):

$$
\begin{aligned}
& f_{\text {opt }}=(-1 / d) \\
& \operatorname{MSY}=(-1 / d) \times \exp ^{(c-1)}
\end{aligned}
$$

Catch per fishing effort $\left(\mathrm{U}_{\mathrm{MSY}}\right)$ is calculated using the formula (13):

$$
\mathrm{U}_{\mathrm{MSY}}=\left(\mathrm{Y}_{\mathrm{MSY}} / \mathrm{fMSY}\right)
$$

The estimated value of allowable catches $\left(\mathrm{Y}_{\mathrm{TAC}}\right)$ uses the formula (14):

$$
\mathrm{Y}_{\mathrm{TAC}}=\quad(-1 / \mathrm{d}) \times \exp ^{(\mathbf{c}-1)} \times 80 \%
$$




\subsection{Utilization rate}

The level of utilization of fish resources can be seen from the amount of catch in a certain year compared to the MSY value. The utilization rate is expressed as a percentage (\%) and can be calculated using the formula :

$$
\mathrm{TP}=\left(\mathrm{Yi} / \mathrm{Y}_{\mathrm{TAC}}\right) \mathrm{X} 100 \%
$$

$\mathrm{TP}=$ utilization rate in year-i, $\mathrm{Yi}=$ catch year-i, $\mathrm{Y}_{\mathrm{TAC}}=$ allowable catch amount

\subsection{Fishing gear standardization}

Fishing gear standardization aims to make the fishing effort unit of each different fishing gear in the same unit. Standardization is used to unify the unit of effort into one standard fishing gear unit. Standardization needs to be done because the type of fishery in Indonesian waters is multi-species and multi-gear. Shortfin scad (D. macrosoma) landed at Pengambengan AFP are caught by various types of fishing gear, including purse seine, gillnets, and hand lines. The fishing gear that is used as standardization is the purse seine because it has complete time series data and is the dominant fishing gear [12]

\subsection{Length-weight relationship}

Length and weight relationship of shortfin scad (D. macrosoma) can be analyzed based on equation [13] as follows:

$$
\mathrm{W}=\mathrm{a} \mathrm{L}^{\mathrm{b}}
$$

$\mathrm{W}=$ weight $($ gram $), \mathrm{L}=$ length $(\mathrm{cm}), \mathrm{a}=$ intercept, $\mathrm{b}=$ estimation of growth pattern

Equation (18) is then transformed into a linear equation:

$$
\operatorname{Ln} \mathrm{W}=\operatorname{Ln} \mathrm{a}+\mathrm{b} \operatorname{Ln} \mathrm{L}
$$

Determination of the growth pattern is carried out by a further test using a t-test. Suppose the value of $t$-count is less than the value of $t$-table $\left(\mathrm{T}_{\text {count }}<\mathrm{T}_{\text {table }}\right)$, the growth is considered as isometric. In contrast, if the value of t-count is higher than the value of t-table $\left(\mathrm{T}_{\text {count }}>\right.$ $\mathrm{T}_{\text {table}}$ ) the growth is considered allometric. Allometric is divided into 2, namely negative allometric $(\mathrm{b}<3)$ and positive allometric $(\mathrm{b}>3)$.

\section{Result}

\subsection{Production volume of shortfin scad (D. macrosoma)}

Based on statistical data of Pengambengan AFP, the production volume of the shortfin scad (D. macrosoma) catch during the last 12 years (2008-2019), which was caught by the purse seine, has fluctuated with an average production reaching 1,580 tons/year. From 2008 to 2017 , the production volume did not reach 1,500 tons/year, and then in 2018, it increased dramatically to more than three times with a total catch of 3,357 tons. The production volume then increased by 400 tons in 2019 (Table 1.). 
Table 1. Production volume (catch), effort, CPUE, and LN CPUE of shortfin scad ( $D$. macrosoma) 2008-2019 in Bali Strait landed in Pengambengan AFP.

\begin{tabular}{|c|c|c|c|c|}
\hline Year & Effort (Trip) & Catch (Ton) & CPUE & LN CPUE \\
\hline 2008 & 2142 & 1273 & 0.59 & -0.52 \\
\hline 2009 & 2909 & 1236 & 0.42 & -0.86 \\
\hline 2010 & 607 & 1389 & 2.29 & 0.83 \\
\hline 2011 & 1874 & 1348 & 0.72 & -0.33 \\
\hline 2012 & 2722 & 1050 & 0.39 & -0.95 \\
\hline 2013 & 2380 & 1175 & 0.49 & -0.71 \\
\hline 2014 & 3662 & 1300 & 0.35 & -1.04 \\
\hline 2015 & 2800 & 1010 & 0.36 & -1.02 \\
\hline 2016 & 2012 & 1028 & 0.51 & -0.67 \\
\hline 2017 & 1224 & 1045 & 0.85 & -0.16 \\
\hline 2018 & 1825 & 3357 & 1.84 & 0.61 \\
\hline 2019 & 2744 & 3757 & 1.37 & 0.31 \\
\hline
\end{tabular}

\subsection{Schaefer model (1954)}

Catch per unit effort (CpUE) can be obtained by the number of fishing efforts that are not fixed per year. The statistical data also shows changes in the fishing effort every year, which shows such a large value. If there is an increase in uncontrolled fishing efforts in the coming years, it will certainly greatly affect the productivity of the catch. Schaefer's (1954) model is calculated by applying regression toward total effort and CpUE. The linear regression results of Schaefer's (1954) model resulted in a relationship between CpUE and the effort of shortfin scad (D. macrosoma) (Figure 2).

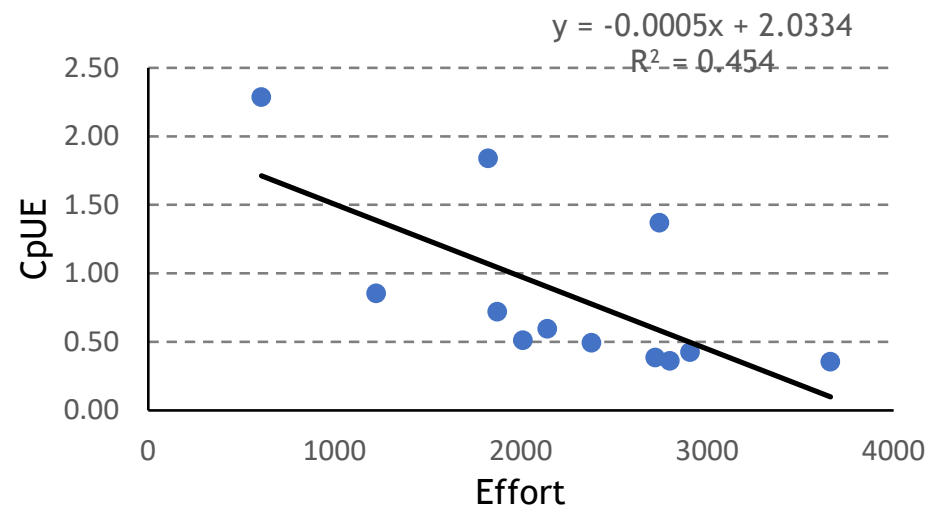

Fig. 2. The relationship of CpUE - Effort Schaefer's model (1954).

The results of the linear regression calculation produce the equation $\mathrm{Y}=-0.0005 \mathrm{x}+$ 2.0334 and $\mathrm{R}^{2}=0.454$ with the value of $\mathrm{a}=2.033$ and $\mathrm{b}=-0.0005$, which means that if one trip increases effort, it will reduce CpUE by 0.0005 ton/trip. The $a$ and $b$ values are then entered in the equation $\mathrm{f}_{\mathrm{MSY}}=-\mathrm{a} / 2 \mathrm{~b}$ and $\mathrm{Y}_{\mathrm{MSY}}=-\mathrm{a}^{2} / 4 \mathrm{~b}$, and the MSY curve of Schaefer's (1954) model is obtained (Figure 3). The estimated value of MSY of shortfin scad ( $D$. 
macrosoma) using the Schaefer model (1954) obtained a result of 1,957 tons/year with an optimum fishing effort $\left(\mathrm{f}_{\mathrm{opt}}\right)$ of 1,925 trips/year. Hence the value of TAC was 1,566 ton/year.

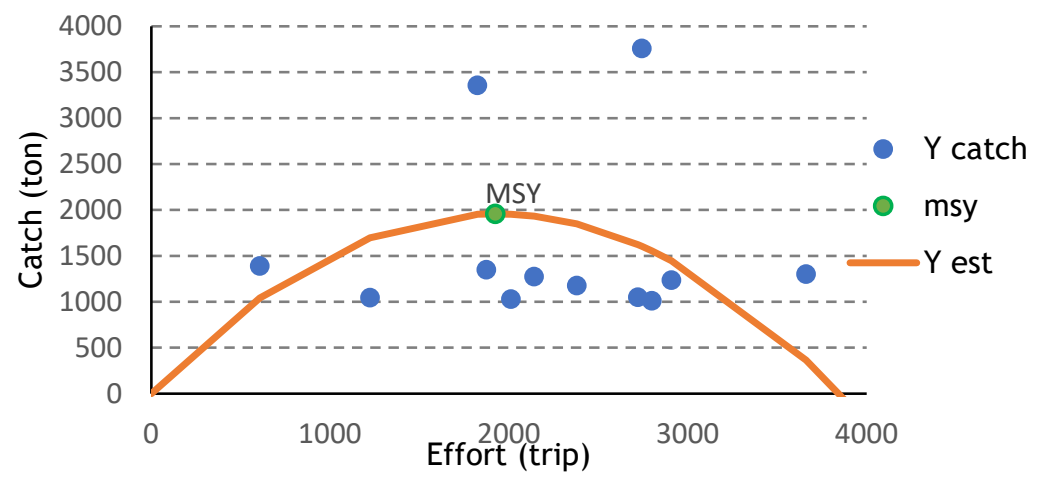

Fig. 3. Maximum Sustainable Yield (MSY) of Schaefer's model (1954).

\subsection{Fox model (1970)}

The results of the linear regression calculation obtained are in the form of the equation $\mathrm{Y}=$ $0.0006 \mathrm{x}+0.882$ and $\mathrm{R}^{2}=0.506$ where the value of $\mathrm{c}=0.882$ and $\mathrm{d}=-0.0005$, which means that if one increase of effort is made, it will reduce CpUE by 0.0005 ton/trip (Figure 4).

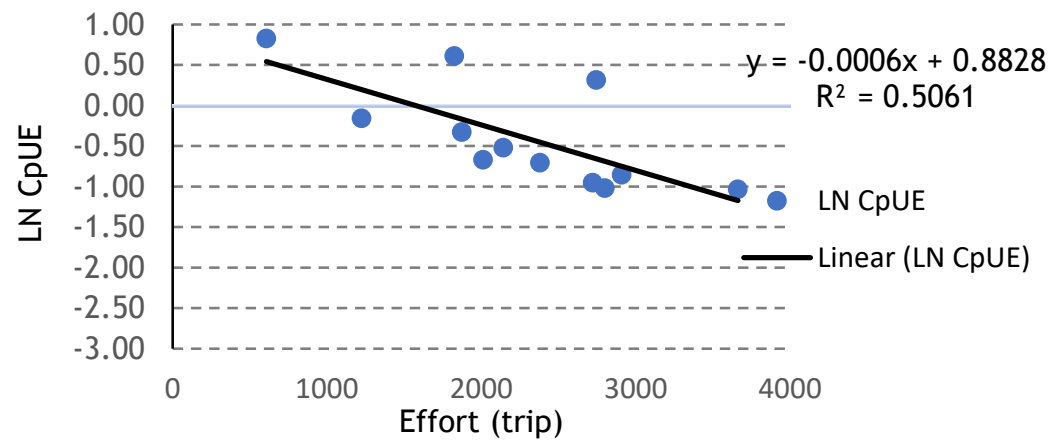

Fig. 4. The relationship of Ln CpUE and effort of Fox model (1970).

The estimated value of Maximum Sustainable Yield (MSY) shortfin scad ( $D$. macrosoma) using the Fox model (1970) obtained a result of 1,585 tons/year with an optimum effort $\left(\mathrm{F}_{\mathrm{opt}}\right)$ of 1,782 trips/year (Figure 5). Hence the value of TAC was 1,268 tons/year. Based on the estimation of the Fox model (1970), it can be seen that in 2016 the utilization rate was below the MSY curve, which means that the number of catches and efforts was still below the MSY value. Apart from 2011 and 2014, the catch was still below the MSY rate, but the catch effort exceeded the optimum effort. The highest effort occurred in 2010, namely 3,675 trips/year or $36 \%$ higher than the optimum effort number. 


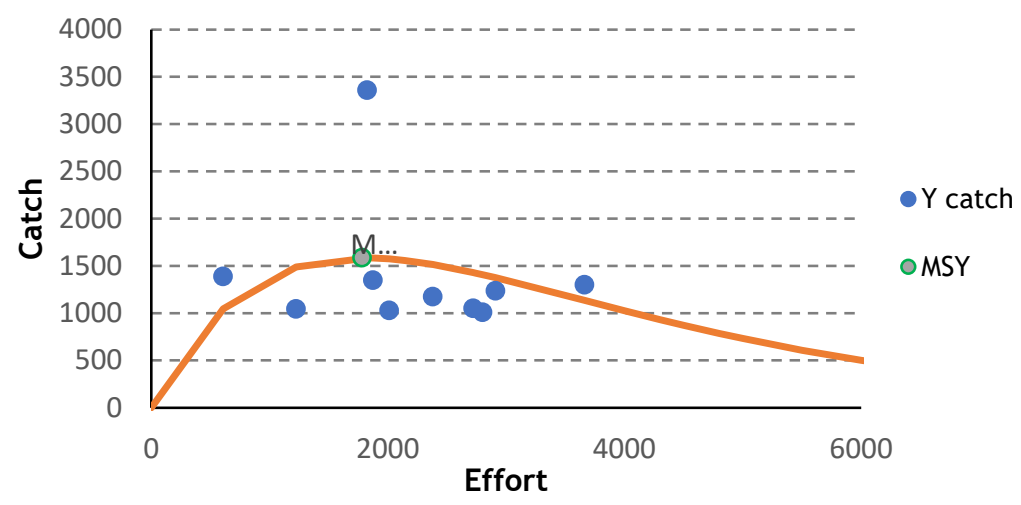

Fig. 5. Maximum Sustainable Yield (MSY) of Fox Model (1970).

\subsection{Length frequency distribution}

The length and weight measurement results of shortfin scad (D. macrosoma) caught in Bali Strait in February - March 2020 landed at Pengambengan AFP obtained a total sample of 1,115 fish and spread over 11 interval classes. The distribution of length-frequency was in the range of $16.5-22 \mathrm{~cm}$. The dominant catch was occupied by an interval class of 18-18.5 $\mathrm{cm}$ with a total sample of 217 fish. In contrast, the least sample belonged to the $16.5-17 \mathrm{~cm}$ (Fig. 6.).

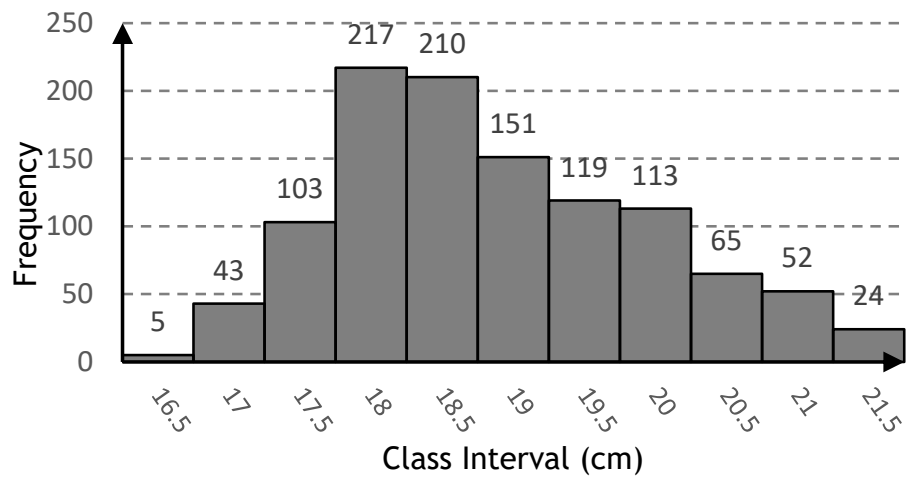

Fig. 6. Length distribution of samples of shortfin scad (D. macrosoma) caught in Bali Strait.

\subsection{Length weight relationship}

Based on the results of linear regression analysis, the relationship between the length and weight of shortfin scad (D. macrosoma) obtained the equation $\mathrm{W}=0.0175 \mathrm{~L}^{2.776}$ with an $\mathrm{R}^{2}$ value equal to 0.77 and $b$ value of 2.776 (Fig.7). The $\mathrm{R}^{2}$ value is the coefficient determination value of shortfin scad's length and weight relationship (D. macrosoma), which means that the length affects weight by $77 \%$. While the value of $b<3$ states that the growth pattern is negative allometric, which means that the increase of fish length is faster than that of fish weight. 


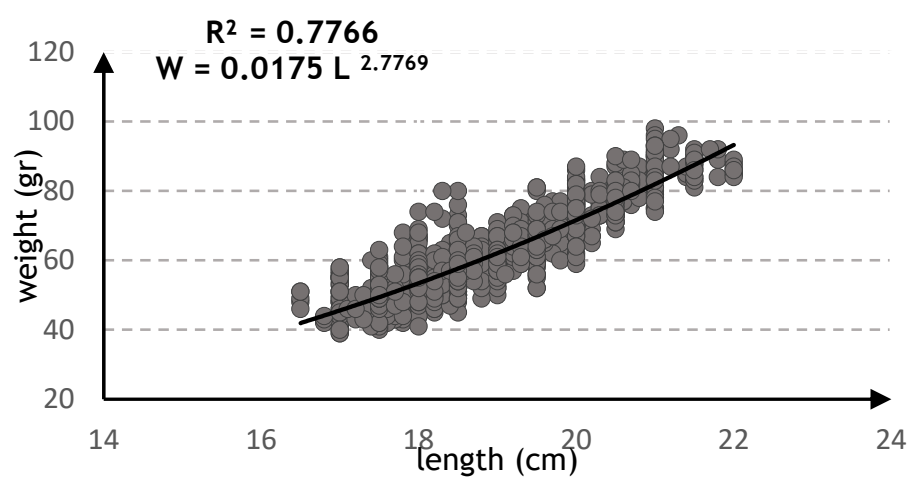

Fig. 7. Length-weight relationship of shortfin scad (D. macrosoma) in Bali Strait.

\section{Discussion}

The MSY curve of the Schaefer model (1954) shows that the production and effort of shortfin scad (D. macrosoma) in the 12 years (2008-2019) landed in Pengambengan AFP has reached overexploited with a utilization rate of $101 \%$. The overexploitation will occur when the level of fishing effort and catch in a fishery resource exceeds the Maximum Sustainable Yield (MSY) limit. Meanwhile, the MSY curve of the Fox model (1970) shows that the production and catching effort of shortfin scad (D. macrosoma) over the 12 years (2008-2019) landed at Pengambengan AFP has reached overexploited with a utilization rate of $125 \%$ [14].

Both models cannot be proven that one model is better than the other. The choice of one model is based on the fact that one of these models is the most rational and approaches the actual situation according to existing data [15]. This trend is indicated by the $\mathrm{R}^{2}$ value or the coefficient of determination which shows how far the two variables influence the catch of shortfin scad (D. macrosoma). The model with the most significant R2 value is suitable for analyzing the data because it shows that the variable $\mathrm{x}$ has a significant effect on the $\mathrm{y}$ variable (Table 2.).

Table 2. The results analysis of Schaefer's model (1954) and Fox's Model (1970)

\begin{tabular}{lll}
\hline Parameters & Schaefer (1954) & Fox (1970) \\
\hline $\mathrm{a}$ & 2.033 & \\
$\mathrm{~b}$ & -0.0005 & \\
$\mathrm{c}$ & & 0.882 \\
$\mathrm{~d}$ & & -0.0005 \\
$\mathrm{R}^{2}$ & 0.454 & 0.506 \\
$\mathrm{f}_{\text {opt }}$ (trip/year) & 1,925 & 1,782 \\
YMSY (ton/year) & 1,957 & 1,585 \\
UMSY (ton/trip) & 0.51 & 0.89 \\
YTAC (ton/year) & 1,566 & 1,268 \\
Utilization rate & $101 \%$ & $125 \%$ \\
Stock status & Over exploited & Over exploited \\
\hline
\end{tabular}

Based on the analysis of the two models, Fox's (1970) model has a greater $\mathrm{R}^{2}$ value. So that according to the Fox (1970) model, the utilization status of the shortfin scad $(D$. macrosoma) resource at Pengambengan AFP is over-exploited, which means that the resource has been exploited beyond the MSY limit. Based on the calculation of the Fox model (1970), the $\mathrm{f}_{\mathrm{opt}}$ value is 1,782 trips/year, and $\mathrm{Y}_{\mathrm{TAC}}$ is 1,268 tons/year. The amount of allowable 
catch and optimum fishing effort from the Fox model (1970) uses the precautionary principle to maintain the sustainability of the shortfin scad (D. macrosoma) resource in Bali Strait. Hence, it is recommended that relevant stakeholders control the effort and catch to sustain the resource of shortfin scad (D. macrosoma) in Bali Strait.

Efforts to manage the Shortfin scad (D. macrosoma) resource can be carried out by regulating the fishing effort in the form of the number of trips and the number of fishing gears used in exploiting. Besides, it can also be done by controlling the catch quota to avoid overexploitation, which leads to biological overfishing when it passes the maximum sustainable value. Overfishing and continuous efforts without responsible and sustainable management can cause a continuation of population degradation with extinction. The potential for sustainable fisheries must indicate the number of fish allowed to be exploited so that fish stocks can be preserved [10].

The length-weight relationship of shortfin scad (D. macrosoma) obtained the b value of 2.7769 , which means that the growth pattern is negative allometric. This value explains that the increase in fish length is faster than that of fish weight, so the body of shortfin scad $(D$. macrosoma) in Bali Strait is thin.

The value of $b$ varies due to several factors such as sampling time and location, number and size of samples, type and size of fishing gear used, geographic location, fish diet, and physiological conditions such as temperature and salinity [16].

\section{Conclusion}

The utilization status of shortfin scad (D. macrosoma) in Bali Strait was at an over-exploited level with a utilization rate as high as $125 \%$. According to Fox model analysis, values of maximum sustainable yield $\left(\mathrm{Y}_{\mathrm{MSY}}\right)$, optimum fishing effort $\left(\mathrm{f}_{\mathrm{opt}}\right)$, and total allowable catch ( $\mathrm{Y}_{\mathrm{TAC}}$ ) were 1,585 tons/year, 1,782 trips/year, and 1,268 tons/year, respectively. The lengthweight relationship of the shortfin scad (D. macrosoma) was negative allometric with equation $\mathrm{W}=0.0175 \mathrm{~L}^{\mathbf{2 . 7 7 6}}$. Hence the stock has to be maintained carefully, and fishing effort must be decreased.

\section{Acknowledgments}

This research was funded by professor and doctor luan program number 55/2019 FPIK Universitas Brawijaya. The authors sincerely thank Fisheries and Marine Science Faculty, Universitas Brawijaya, and Pengambengan Archipelago Fishing Port for their constant encouragement and support. We also thank all staff members of Fisheries Resource Utilization Study Program FPIK Universitas Brawijaya For their help during the research activity. Last but not least, our thank goes to Dr. Fauziyah from Universitas Sriwijaya, who has given excellent correction to this article.

\section{References}

1. T. Shiraishi, H. Tanaka, S. Ohshimo, H. Ishida, N. Morinaga, Japan Agr. Res. Quart.: JARQ. 44, 2 (2010)

2. S. Koeshendrajana, I.W. Rusastra, P. Martosubroto, Potential of marine and fisheries resources of WPPNRI 573 (in Bahasa Indonesia) (AMAFRAD Press, Jakarta, 2019)

3. N. Zulbainarni, M. Tambunan, Y. Syaukat, A. Fahrudin, Mar. Fish. 2, 2 (2011)

4. S. Suwarso, A. Zamroni, J. Indo. Fish. Pol. 6, 2 (2015)

5. R.L. Bubun, A. Mahmud, J. Airaha 5, 1 (2016) 
6. M. Sururi, M. Mustasim, F. Hoek, A. Anasri, J. Airaha 6, 1 (2017)

7. H. Hulaifi, J. Math. Educ. Sci. Technol. 12, 2 (2011)

8. A. Suman, Wudianto, B. Sumiono, Status of fish resource utilization in Indonesia with the Tomini Bay case (in Bahasa Indonesia) (IPB Press, Bogor, 2011)

9. B.M. Sukojo, L. Zahroh, J. Geod and Geomatics (Geoid). 13, 1 (2018)

10. H. Latukonsina J. Agri. and Fish. Sci. 3, 2 (2010)

11. J.S. Kekenusa, S.B. Rondonuwu, M.S. Paendong, IOP Conf. Ser. Mater. Sci. Eng. 567, 13 (2019)

12. Susiana, Rochmady, J. of Waters Utilization 1, 1 (2018)

13. I.M.S.K. Sravishta, I.W. Arthana, M.A. Pratiwi, J. of Mar. and Aq. Sci. 4, 2 (2018)

14. D.H. Mayu, Kurniawan, A. Febrianto, J. Capt. Fish. 2, 1 (2018)

15. P. Sparre, S.C. Venema, Introduction to tropical fish stock assessment (FAO, Rome, 1999)

16. A. Ahmadi, J. Fish. \& Aq. Life 28, 113-124 (2020) 